\title{
The Regulation and Function of Fibroblast Growth Factor 8 and Its Function during Gonadotropin-Releasing Hormone Neuron Development
}

\author{
Wilson C. J. Chung*, Megan L. Linscott, Karla M. Rodriguez and Courtney E. Stewart \\ Department of Biological Sciences, School of Biomedical Sciences, Kent State University, Kent, OH, USA
}

OPEN ACCESS

Edited by:

T. John Wu,

Uniformed Services University of the Health Sciences, USA

Reviewed by:

Charles Roselli,

Oregon Health \&

Science University, USA

Kun Don Yi,

Syngenta Crop Protection,

LLC. USA

*Correspondence:

Wilson C. J. Chung

wchung@kent.edu

Specialty section:

This article was submitted to Experimental Endocrinology,

a section of the journal

Frontiers in Endocrinology

Received: 18 April 2016 Accepted: 08 August 2016 Published: 05 September 2016

Citation:

Chung WCJ, Linscott ML Rodriguez KM and Stewart CE (2016)

The Regulation and Function

of Fibroblast Growth Factor

8 and Its Function during

Gonadotropin-Releasing Hormone Neuron Development.

Front. Endocrinol. 7:114. doi: 10.3389/fendo.2016.00114
Over the last few years, numerous studies solidified the hypothesis that fibroblast growth factor (FGF) signaling regulates neuroendocrine progenitor cell proliferation, fate specification, and cell survival and, therefore, is critical for the regulation and maintenance of homeostasis of the body. One important example that underscores the involvement of FGF signaling during neuroendocrine cell development is gonadotropin-releasing hormone $(\mathrm{G} R \mathrm{RH})$ neuron ontogenesis. Indeed, transgenic mice with reduced olfactory placode (OP) Fgf8 expression do not have GnRH neurons. This observation indicates the requirement of FGF8 signaling for the emergence of the $\mathrm{GnRH}$ neuronal system in the embryonic OP, the putative birth place of $\mathrm{GnRH}$ neurons. Mammalian reproductive success depends on the presence of $\mathrm{GnRH}$ neurons to stimulate gonadotropin secretion from the anterior pituitary, which activates gonadal steroidogenesis and gametogenesis. Together, these observations are critical for understanding the function of $\mathrm{GnRH}$ neurons and their control of the hypothalamus-pituitary-gonadal (HPG) axis to maintain fertility. Taken together, these studies illustrate that $\mathrm{GnRH}$ neuron emergence and hence HPG function is vulnerable to genomic and molecular signals that abnormally modify Fgf8 expression in the developing mouse OP. In this short review, we focus on research that is aimed at unraveling how androgen, all-trans retinoic acid, and how epigenetic factors modify control mouse OP Fgf8 transcription in the context of GnRH neuronal development and mammalian reproductive success.

Keywords: Fgf8, GnRH, androgen receptor, retinoic acid, epigenetics, olfactory placode

\section{INTRODUCTION}

Fibroblast growth factor (FGF) 8 (FGF8) signaling regulates neuroendocrine progenitor cell proliferation, fate specification, and cell survival and has therefore been hypothesized to be critical for the development and maintenance of homeostatic systems in the body such as the hypothalamus-pituitary-axis (HPG) (1-5). Indeed, FGF8 has been shown to be critical for emergence of gonadotropinreleasing hormone $(\mathrm{GnRH})$ neurons $(1,2,6)$. Later studies also demonstrated that FGF8 affects the postnatal maturation of vasopressin, oxytocin, kisspeptin, and corticotropin-releasing hormone neurons found in the mammalian hypothalamus $(1,2,4,6-8)$. 
In humans, Fgf8 point mutations cause Kallmann syndrome (KS), a form of congenital hypogonadotropic hypogonadism $(\mathrm{HH})$ that is associated with anosmia $(6,9)$. Generally, KS patients do not undergo puberty and are infertile in adulthood. These observations indicate that embryonic disruptions in FGF8 signaling can abrogate $\mathrm{GnRH}$ neuronal development and hence cause infertility. Genetic screenings of individuals with $\mathrm{GnRH}$ deficiencies identified that Fgf8 is not the only gene that is important for GnRH (progenitor) cell development, fate specification, and migration $(3,5,10,11)$. Indeed, $\mathrm{KS}$ patients can also harbor mutations in anosmin-1 (12-14), fibroblast growth factor receptor-1 (Fgfr1) (15), prokineticin 2 (16) and its receptor (17), and chromodomain helicase-DNA-binding 7 (18). In this short review, we limit our discussion to the role of FGF8 signaling during GnRH neuron emergence and how Fgf8 transcriptional activity may be controlled during olfactory placode (OP) development.

The majority of the evidence indicating that FGF8 function is required for the emergence and possibly function of $\mathrm{GnRH}$ neurons is derived from studies investigating how FGF8 signaling controls the emergence of the GnRH neuronal system in humans and mice $(2,3,5,6,11,19-21)$. FGF8 is a member of the large FGF signaling family (22) that can act through four membranebound tyrosine kinase FGF receptors (FGFRs) in humans and mice (23-26). Stable binding of FGFs in the presence of heparin proteoglycans enables FGFR dimerization and initiates a myriad of intracellular signal transduction pathways (27). The inherent complexity of the FGF signaling system and their functional redundancy demonstrates the robustness of FGF signaling during embryonic development (28).

Two landmark studies published in the late 1980s have been essential in understanding where and when FGF8 signaling is critical during the development of the GnRH neuronal system $(29,30)$. Indeed, these studies presented convincing evidence that hypothalamic GnRH neurons in rodents and humans are born specifically in the medial OP (mOP) (Figure 1). A surprising finding, which meant that the OP morphogenetic region, which was generally known to be the anatomical precursor of the frontonasal facial structures $(29,30)$, also gave rise to a very specific and important hypothalamic neuroendocrine cell population.

Proliferation studies indicate that $\mathrm{GnRH}$ progenitor cells become postmitotic around embryonic day (E) $9.5(30,31)$. Following their emergence from the mOP, GnRH neurons migrate along the nasal septum, all the while following the olfactory, vomeronasal, and terminal nerves to the preoptic area and hypothalamus $(2,10,30,31)$. Postnatally, the majority of $\mathrm{GnRH}$ neurons are localized around the anterior tip of the third ventricle called organum vasculosum lamina terminalis in the preoptic area and project their axons to the external zone of the median eminence. Upon stimulation, they release the $\mathrm{GnRH}$ decapeptide into the portal vein system to activate gonadotropin release and production from gonadotrophs in the anterior pituitary into the systemic circulation, ultimately stimulating gonadal steroidogenesis and gametogenesis $(3,5)$. In the following sections, we will describe what is known about the emergence of GnRH neurons in the mOP, the role of FGF8 signaling, and how FGF8 transcription may be controlled during the mid-gestational development of the mouse OP.

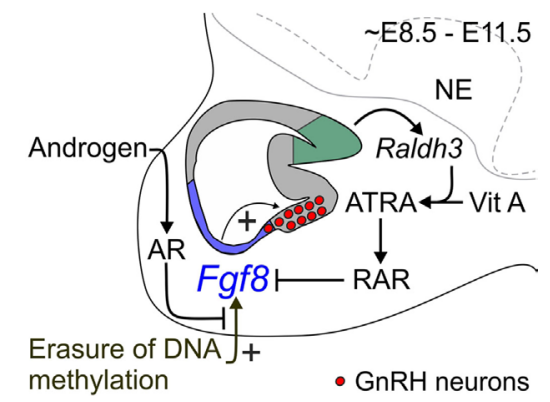

FIGURE 1 | Proposed mechanism for coordinate regulation of transient $\boldsymbol{F g f 8}$ transcription in the mouse OP. Sagittal schematic representation of the $\sim$ E8.5-E11.5 mouse nasal region. FGF8 expressing cells located in the respiratory epithelium (blue region) are required for $\mathrm{GnRH}$ neuron emergence in the embryonic mouse mOP (red circles) located in the olfactory epithelium (gray region). Evidence from our and other studies indicates three major signaling mechanisms that regulate transient Fgf8 expression in the embryonic mouse OP. First, our data showed that AR directly interacts with its ARE sites on the Fgf8 promoter region. However, in contrast to our premise, DHT did not upregulate Fgf8 expression in GT1-7 neurons or the embryonic OP. Second, inhibition of DNMT activity upregulated Fgf8 expression suggesting that the erasure of DNA methylation induced Fgf8 promoter activity. Surprisingly, DHT was able to block this effect, which led us to infer that androgen signaling-dependent modulation of Fgf8 transcription in the embryonic OP is reliant on the epigenetic status of the Fgf8 promoter. Third, ATRA signaling clearly inhibits Fgf8 expression. The embryonic OP exhibits an age-dependent increase in ATRA levels due to the local upregulation of Raldh3 expression [converts vitamin (Vit) A to ATRA] in the dorsal-caudal region olfactory epithelium (green region), which then acts through RARs to inhibit Fgf8 expression. These data led us to update our hypothesis as to how transient Fgf8 transcription is controlled in the embryonic mouse OP: upregulation of Fgf8 transcriptional activity is DNA methylation-dependent, which is subsequently downregulated through androgen and/or ATRA signaling. In this context, androgen and/or ATRA signaling may act as a transcriptional brake to limit FGF8's morphogenetic or proliferative effects on the embryonic mouse OP. NE, neurepithelium.

\section{ONTOGENESIS OF THE GnRH NEURONAL SYSTEM}

Two independent studies found that GnRH expressing neurons emerge from the $\operatorname{mOP}(30,31)$. Interestingly, proliferation studies indicated that the vast majority ( $80 \%)$ of mouse $\mathrm{GnRH}$ neurons become postmitotic in the mOP between E9.5 and E10.5 (29), which not only indicates that the birth place of $\mathrm{GnRH}$ progenitor cells is very likely localized in the embryonic mOP but also that GnRH-neuron fate specification occurs prior to E9.5.

The OP is an ectodermal region that gives rise to (non-sensory) respiratory epithelium and (sensory) olfactory epithelium (32-34). The olfactory epithelium develops into the main olfactory and vomeronasal systems $(35,36)$. Ablation studies support that the $\mathrm{mOP}$ is the birthplace of GnRH neurons. For example, amphibians that undergo OP removal ultimately lack the olfactory epithelium, nerve, and bulb, as well as GnRH neurons of the forebrain (37, 38). On the other hand, chick studies indicate that GnRH neurons emerge from the respiratory epithelium rather than the olfactory epithelium (39). Indeed, surgical removal of the respiratory, but not olfactory epithelium, eliminated GnRH neurons $(40,41)$. Mouse studies showed that the birth place of GnRH neurons may 
overlap with a very small portion of the respiratory epithelium that borders the olfactory epithelium (34). Overall, these data indicate that both the respiratory and olfactory epithelium contribute to the OP's ability to generate GnRH neurons.

Migrating neural crest cells also contribute to the pool of $\mathrm{GnRH}$ progenitor cells. The bilateral neural crest region arises from the edge of the neural plate and shares a border with the region that eventually becomes the OP. Indeed, migrating neural crest cells contribute to the formation of the OP (42-44). As shown in zebrafish experiments, some anterior neural crest cells migrate toward the presumptive $\mathrm{OP}$ and contribute specific cell populations to the developing OP (45). Pre-migratory neural crest cells labeled with rhodamine dextran in vivo $(46,47)$ also double-labeled for GnRH mRNA and peptide (48). Similar data have also been found in mouse studies, which indicate that $\sim 30 \%$ of the GnRH neurons found in the mOP exhibited a genetic lineage similar to neural crest cells $(43,49)$. The remaining $70 \%$ of the total population of $\mathrm{GnRH}$ neurons were confirmed to be of placodal origin. In short, the progenitor cells that develop into GnRH neurons are likely to originate from the neural crest and the OP.

\section{FIBROBLAST GROWTH FACTORS AND THEIR RECEPTORS}

As indicated earlier, FGFs are well-known signaling proteins that are crucial for fate specification, migration, differentiation, and survival (50). There are 22 members of the FGF signaling family found in the mouse (22). Homology between FGFs is based on the presence of a highly conserved 120 amino acid core region, and the $30-60 \%$ overall amino acid identity across all FGFs (22). The presence of a $\mathrm{N}$-terminal signal peptide sequence in most FGF ligands indicates that they are secreted into the extracellular milieu (51).

Fibroblast growth factor signaling is facilitated through membrane-bound tyrosine kinase receptors that contain an extracellular ligand-binding domain, a transmembrane domain, and an intracellular tyrosine kinase domain. In some instances, FGFRs translocate to or reside in the cell nucleus (23-26). Currently, four FGFRs have been identified in humans and mice. The extracellular region of a FGFR is characterized by the presence of three immunoglobulin (Ig)-like domains and one heparin-binding domain. Stable binding of FGFs in the presence of heparin sulfate proteoglycans causes dimerization of FGFRs and phosphorylation of cytoplasmic tyrosine residues in the kinase domain. This, in turn, initiates a myriad of intracellular signal transduction pathways including the phosphorylation of $\mathrm{SH} 2$ domain of phospholipase $\mathrm{C} \gamma$, hydrolysis of phosphatidylinositol bisphosphate to diacylglycerol and inositol trisphosphate, resulting in intracellular changes in $\mathrm{Ca}^{2+}$. FGFRs also activate the ERK pathway, specifically ERK1 and ERK2 (27). In addition, FGF signaling can activate the PI3K/AKT pathway, which in turn protects against apoptosis by inhibiting caspases $(52,53)$. The analysis of alternative FGFR mRNA splicing revealed that the third Ig-like domain comes in three versions, referred to as IIIa, IIIb, or IIIc and are expressed in a tissue-specific manner. Indeed, the IIIa form of FGFRs is secreted into extracellular environment, whereas the IIIb and IIIc forms of FGFRs are preferentially present in epithelial cells and mesenchymal cells, respectively (28). Binding affinity studies based on mitogenic activity showed that FGFRs can bind a variety of FGF ligands, indicating the presence of functional redundancy. For example, signaling of the subfamily of FGF8, 17, and 18 occurs preferentially through FGFR3c < FGFR4c $<$ FGFR2c $<$ FGFR1c $<<$ FGFR3b (28). On the other hand, recent studies using surface plasmon resonance analysis detected that the binding affinity of the FGF8b splice variant (i.e., Kd) to FGFR1 $\approx$ FGFR2 $\approx$ FGFR3 indicating that FGF8 signaling may be mediated equally by FGFR1, FGFR2, or FGFR3 (54). The complexity and redundancy in FGF ligands and receptors demonstrates the inherent robustness of FGF signaling during embryonic development.

\section{FGF8 IS REQUIRED FOR GnRH NEURON EMERGENCE}

Studies in humans and rodents have confirmed the concept that FGF8 signaling is critically important for the emergence of the GnRH neuronal system $(1,2,6,20,21)$. Indeed, GnRH neurons are absent in homozygous $F g f 8$ hypomorphic embryonic and newborn mice $(2,6)$. Not surprisingly, the number of $\mathrm{GnRH}$ neurons was also reduced in heterozygous $F g f 8$ hypomorphs when compared to wildtype mice $(2,6)$. Later studies further showed that the deficit in GnRH neurons delayed puberty in female mice, even though recent studies indicate that FGF8 dysfunction did not reduce adult male or female hypothalamic GnRH peptide synthesis, except on postnatal day $60(4,21)$. Together, these results provided a fundamental explanation for the reproductive defects found in KS patients who harbor hemizygous $\mathrm{Fgf8}$ mutations (55).

The elimination of $\mathrm{GnRH}$ neurons likely occurred during the emergence phase of GnRH neuronal development ( E9.5E10.5). Currently, we do not know whether the elimination of the GnRH progenitor cells is due to abrogated FGF8-dependent proliferation or cell survival. However, evidence favors the second possibility given that the presence of increased apoptosis has been reported in the E10.5 OP of mice with reduced $\mathrm{Fg} f 8$ expression (5). Moreover, studies in conditional Fgf8 null mice found that apoptosis in the OP was much higher in wildtype mice on E10.5. In contrast, no difference was found in the level of cell proliferation (56). Therefore, attenuated FGF8 expression in the early embryonic OP likely abrogated the survival of $\mathrm{GnRH}$ (progenitor) cells.

Studies in the chicken embryos confirmed that the timing of FGF8 signaling is critical for the emergence of the GnRH in the OP (57), which occurs around Hamburger and Hamilton (HH: time after egg-laying) 19. HH17 chick OP explant cultures will express GnRH mRNA after 2 days in culture, which the FGFR antagonist SU5402 prevented. On the other hand, exogenous FGF8 induced and could advance chick GnRH mRNA expression (57). These studies confirmed our conclusion that the timing of transient FGF8 signaling is critical for the emergence of $\mathrm{GnRH}$ neurons in the OP (2). Interestingly, exogenous FGF8 had unexpected effects on mouse GT1-7 GnRH-secreting neurons. These studies showed that treatment with the most abundant FGF8b 
splice form inhibited GnRH mRNA expression (58). These contrasting data sets could indicate that FGF8 affects $\mathrm{GnRH}$ neuron development in a bi-phasic fashion. First, FGF8 initially acts as a neurotrophic factor to prevent the elimination of $\mathrm{GnRH}$ progenitor cells, thereby allowing the emergence of the $\mathrm{GnRH}$ neuronal system from the mOP. Second, it has to be recognized that FGF8 also functions as morphogenetic factor that maintains the proliferative character of progenitor cells (59-63). Therefore, continued FGF8 function on GnRH neurons could result in the dedifferentiation of fate-specified cells, such as GT1-7 neurons.

Recent cell lineage studies confirmed that $F g f 8$ mRNA is primarily localized in the respiratory epithelium (64). More importantly, these studies also indicate that GnRH neurons are not derived from $F g f 8$ expressing respiratory epithelium progenitor cells $(11,32)$. Therefore, we conclude that Fgf8 expressing respiratory epithelial cells may provide trophic support, which promotes the survival of E9.5-E10.5 GnRH progenitor cells in the mOP (Figure 1).

\section{ANDROGEN EFFECTS ON TRANSIENT OP Fgf8 TRANSCRIPTION}

Earlier studies indicate that mouse OP Fgf8 mRNA expression upregulates around embryonic day (E) 8.5 followed by a downregulation around $\mathrm{E} 11.5 / 12.5(61,63,65,66)$. FGF8 was originally discovered as an androgen-induced growth factor in SC-3 cells, an androgen-dependent mouse breast cancer cell line (67). Studies also showed that testosterone induced $\mathrm{Fg} f 8$ mRNA in LNCaP cells (68). In vitro analysis showed that androgen-bound androgen receptors (ARs) act on androgen response elements (AREs) to activate Fgf8 promoter-coupled luciferase activity, which was inhibited with the anti-androgens (69). Functional deletion studies showed that androgen activates Fgf8 transcription through these putative AREs in the Fgf8 promoter (69). Our data confirmed that the embryonic mouse OP expresses high AR mRNA levels, while ChIP qPCR quantification found that AR interacts with three AREs on the mouse Fgf8 promoter in GT1-7 neurons and OP explants, in an androgen-independent fashion (70). These results led us to conclude that unliganded AR may be responsible for the upregulation of OP Fgf8 transcription between E8.5 and E11.5, to stimulate $\mathrm{GnRH}$ (progenitor) cell emergence/survival. However, our recent studies in mouse OP explants showed that androgen did not modulate $F g f 8$ nor did it affect $G n R H$ mRNA expression (70) suggesting that androgen, unlike in SC-3 or LNCaP cells, is not the primarily regulator of $F g f 8$ transcription in the embryonic mouse OP. However, as discussed later, we cannot fully rule out the possibility that androgen signaling effects on Fgf8 expression depends on the epigenetic status of the $F g f 8$ promoter (Figure 1).

\section{RETINOIC ACID EFFECTS ON TRANSIENT OP Fgf8 TRANSCRIPTION}

On the other hand, it is clear that all-trans retinoic acid (ATRA) signaling is a strong inhibitor of $F g f 8$ expression in the vertebrate OP (Figure 1). For instance, ATRA-soaked beads proximal to the chick OP suppresses virtually all nearby $F g f 8$ expression, which was correlated with a coincident elimination of emerging $\mathrm{GnRH}$ neurons (57). The inhibition of OP Fgf8 expression is thought to be caused by local synthesis of ATRA by RA-synthesizing aldehyde dehydrogenase 3 (RALDH3) from vitamin A in OP cells (Figure 1), which in turn activates retinoid receptors, such as RA receptor (RAR) $\alpha, \beta, \gamma$ in the developing OP $(11,57,71)$. RARs bind ATRA and the stereoisomer 9-cis RA, whereas RXRs only bind to 9-cis RA (72). Although RARs and RXRs act as heterodimeric complexes that affect gene transcription, studies indicate that RXRs primarily act as silent partners with respect to gene transcription (72-74). Moreover, 9-cis RA is absent in the embryonic mouse (72). Data from developmental brain studies clearly showed that ATRA acts to spatially and temporally restrict Fgf8 mRNA expression to achieve polarity in body axis $(75,76)$. Recently, our preliminary data showed that ATRA prevents (unpublished results) the normal upregulation of GnRH expression found in mouse OP explants (70). Therefore, we conclude that ATRA acting through RARs temporally restricts Fgf8 transcription in the mouse $\mathrm{OP}$ region, consequently causing the downregulation of OP cell Fgf8 mRNA levels after E11.5/E12.5.

\section{EPIGENETIC EFFECTS ON TRANSIENT OP Fgf8 TRANSCRIPTION}

As previously mentioned, our recent studies showed that the regulation of $\mathrm{Fgf8}$ transcription is under the control of DNA methylation, a conclusion that is supported by our recently published results (70). Multiple CpG islands upstream and downstream of the translation start site of the Fgf8 gene have been detected (http://www.ncbi.nlm.nih.gov/geo). The presence of these $\mathrm{CpG}$ islands in the $\mathrm{Fgf8}$ gene suggests that $\mathrm{Fgf8}$ transcriptional and mRNA expression in OP cells may be DNA methylation-dependent. DNA methylation depends on DNMTs, which catalyze cytosine methylation in the presence of the methyl group donor $S$-adenosyl methionine (71). Evidence from previous studies indicates that E11.5 olfactory progenitor cells express high levels of DNMTs (77). Specifically, mitotic olfactory progenitors express exclusively DNMT3b, whereas postmitotic olfactory neurons express DNMT3a (77). Interestingly, semiquantitative analysis showed that $D n m t 3 b$ mRNA expression is gradually reduced after E11.5 (77). Together with the rise of Fgf8 transcription between E8.5 and E11.5, we inferred that the Fgf8 gene may initially be heavily methylated followed by a process of DNA demethylation, which is in line with studies indicating that DNMT repression in E7.5-E10.5 mice causes global DNA demethylation, subsequently upregulating global gene expression $(78,79)$. Therefore, we predicted that reducing DNMT activity would induce $F g f 8$ expression. To investigate this possibility, we treated GT1-7 neurons with AZA for 3 days and found that the AZA increased Fgf8 mRNA levels (70). These data support that erasure of DNA methylation due to reduced DNMT-mediated maintenance may induce $F g f 8$ transcriptional activity (80). Currently, we are exploring whether active DNA demethylation facilitated by ten-eleven translocation enzymes potentiates embryonic erasure of DNA methylation in the mouse OP, which has not been studied before.

We do not know whether AZA directly controls DNA methylation status of the Fgf8 promoter; however, previous 
studies indicating that hypomethylation in primary rhabdomyosarcoma tumors was correlated with higher Fgfr 1 mRNA expression levels (81). Our current research focuses on verifying whether DNA demethylation of the $F g f 8$ promoter regions is the underlying molecular mechanism that causes the upregulation of OP Fgf8 expression, possibly through the inhibition of DNMT activity. On the other hand, we cannot rule out the possibility that AZA indirectly elicited the upregulation of Fgf8 expression, such as inducing or inhibiting the expression of AR or RARs.

To our surprise, the non-aromatizable androgen, DHT, eliminated the AZA-dependent rise in Fgf8 mRNA levels, which is the basis of our earlier inference that androgen signaling depends on the epigenetic status of the Fgf8 promoter region. Based on these results, androgen signaling modulation of $F g f 8$ expression may act in concert with other changes in cellular milieu during OP development. One possibility is that, in the context of epigenetic modification of Fgf8 expression, androgen signaling through the AR may act as a transcriptional brake that limits the morphogenetic or proliferative effects of FGF8 signaling due to DNA demethylation-dependent upregulation of $F g f 8$ expression. For instance, a possibility is that the demethylation of the Fgf8 promoter allows the constitutively-bound ARs to recruit corepressors in the presence of DHT. However, this is highly speculative as there are no data supporting this idea. Nonetheless, these results indicate that increased DNA demethylation can induce Fgf8 transcription and that androgen signaling is functionally repressive.

\section{SUMMARY AND CONCLUSION}

Our recent research indicates that transient OP Fgf8 transcription may be due to the coordinated actions of AR, RARs, and

\section{REFERENCES}

1. Chung WC, Matthews TA, Tata BK, Tsai PS. Compound deficiencies in multiple fibroblast growth factor signalling components differentially impact the murine gonadotrophin-releasing hormone system. JNeuroendocrinol (2010) 22(8):944-50. doi:10.1111/j.1365-2826.2010.02024.x

2. Chung WC, Moyle SS, Tsai PS. Fibroblast growth factor 8 signaling through fibroblast growth factor receptor 1 is required for the emergence of gonadotropin-releasing hormone neurons. Endocrinology (2008) 149(10):4997-5003. doi:10.1210/en.2007-1634

3. Stevenson EL, Corella KM, Chung WC. Ontogenesis of gonadotropinreleasing hormone neurons: a model for hypothalamic neuroendocrine cell development. Front Endocrinol (2013) 4:89. doi:10.3389/fendo.2013.00089

4. Tata BK, Chung WC, Brooks LR, Kavanaugh SI, Tsai PS. Fibroblast growth factor signaling deficiencies impact female reproduction and kisspeptin neurons in mice. Biol Reprod (2012) 86(4):119. doi:10.1095/biolreprod.111. 095992

5. Tsai PS, Brooks LR, Rochester JR, Kavanaugh SI, Chung WC. Fibroblast growth factor signaling in the developing neuroendocrine hypothalamus. Front Neuroendocrinol (2011) 32(1):95-107. doi:10.1016/j.yfrne.2010.11.002

6. Falardeau J, Chung WC, Beenken A, Raivio T, Plummer L, Sidis Y, et al. Decreased FGF8 signaling causes deficiency of gonadotropin-releasing hormone in humans and mice. J Clin Invest (2008) 118(8):2822-31. doi:10.1172/ JCI34538

7. Rodriguez KM, Stevenson EL, Stewart CE, Linscott ML, Chung WC. Fibroblast growth factor 8 regulates postnatal development of paraventricular
DNA demethylation, which together provide a permissive transcriptional milieu that initially promotes and later limits the emergence of $\mathrm{GnRH}$ neurons. Indeed, disruption of transient Fgf8 transcription in the OP can eliminate the emergence of the entire GnRH neuronal system suggesting that FGF8's primary function is to provide trophic support for the emerging $\mathrm{GnRH}$ neurons. However, data from GT1-7 neurons indicate that FGF8 causes a reduction in GnRH mRNA expression. Taken together, we conclude that the physiological function of transient Fgf8 transcription is twofold. Initially, the upregulation of FGF8 promotes and provides trophic support required for the emergence of GnRH neurons in the mOP. However, because FGF8 is also known to maintain the undifferentiated nature of progenitor cells, FGF8 expression in the OP region must be downregulated before it dedifferentiates the newly emerged $\mathrm{GnRH}$ neurons. Based on the presented data, we speculate that the coordinated control of transient $F g f 8$ transcription acts as a molecular system that spatially and temporally controls not just the emergence of $\mathrm{GnRH}$ neurons (i.e., total number) but also whether they remain GnRH neurons. In essence, we conclude that transient FGF8 is possibly a major molecular cue that controls the number $\mathrm{GnRH}$ neurons that can emerge from the mOP, which could affect the functionality of the GnRH neuronal system as it pertains to the HPG-axis and reproductive success.

\section{AUTHOR CONTRIBUTIONS}

All authors contributed to the conceptual development and writing of this review.

\section{FUNDING}

This work was funded by NIH R00 HD058044 to WC.

nucleus neuroendocrine cells. Behav Brain Funct (2015) 11(1):34. doi:10.1186/ s12993-015-0081-9

8. Brooks LR, Chung WC, Tsai PS. Abnormal hypothalamic oxytocin system in fibroblast growth factor 8-deficient mice. Endocrine (2010) 38(2):174-80. doi:10.1007/s12020-010-9366-9

9. Lucassen PJ, Chung WC, Kamphorst W, Swaab DF. DNA damage distribution in the human brain as shown by in situ end labeling; area-specific differences in aging and Alzheimer disease in the absence of apoptotic morphology. J Neuropathol Exp Neurol (1997) 56(8):887-900. doi:10.1097/00005072-199708000-00007

10. Miraoui H, Dwyer A, Pitteloud N. Role of fibroblast growth factor (FGF) signaling in the neuroendocrine control of human reproduction. Mol Cell Endocrinol (2011) 346(1-2):37-43. doi:10.1016/j.mce.2011.05.042

11. Forni PE, Wray S. GnRH, anosmia and hypogonadotropic hypogonadism where are we? Front Neuroendocrinol (2015) 36:165-77. doi:10.1016/j. yfrne.2014.09.004

12. Franco B, Guioli S, Pragliola A, Incerti B, Bardoni B, Tonlorenzi R, et al. A gene deleted in Kallmann's syndrome shares homology with neural cell adhesion and axonal path-finding molecules. Nature (1991) 353(6344):529-36. doi: $10.1038 / 353529 \mathrm{a} 0$

13. Legouis R, Hardelin JP, Levilliers J, Claverie JM, Compain S, Wunderle V, et al. The candidate gene for the X-linked Kallmann syndrome encodes a protein related to adhesion molecules. Cell (1991) 67(2):423-35. doi:10.1016/0092-8674(91)90193-3

14. Hardelin JP, Levilliers J, del Castillo I, Cohen-Salmon M, Legouis R, Blanchard S, et al. X chromosome-linked Kallmann syndrome: stop mutations 
validate the candidate gene. Proc Natl Acad Sci U S A (1992) 89(17):8190-4. doi:10.1073/pnas.89.17.8190

15. Dodé C, Levilliers J, Dupont JM, De Paepe A, Le Dû N, Soussi-Yanicostas $\mathrm{N}$, et al. Loss-of-function mutations in FGFR1 cause autosomal dominant Kallmann syndrome. Nat Genet (2003) 33(4):463-5. doi:10.1038/ng1122

16. Dodé C, Teixeira L, Levilliers J, Fouveaut C, Bouchard P, Kottler ML, et al. Kallmann syndrome: mutations in the genes encoding prokineticin-2 and prokineticin receptor-2. PLoS Genet (2006) 2(10):e175. doi:10.1371/journal. pgen.0020175

17. Cole LW, Sidis Y, Zhang C, Quinton R, Plummer L, Pignatelli D, et al. Mutations in prokineticin 2 and prokineticin receptor 2 genes in human gonadotrophin-releasing hormone deficiency: molecular genetics and clinical spectrum. J Clin Endocrinol Metab (2008) 93(9):3551-9. doi:10.1210/ jc.2007-2654

18. Kim HG, Kurth I, Lan F, Meliciani I, Wenzel W, Eom SH, et al. Mutations in $\mathrm{CHD} 7$, encoding a chromatin-remodeling protein, cause idiopathic hypogonadotropic hypogonadism and Kallmann syndrome. Am J Hum Genet (2008) 83(4):511-9. doi:10.1016/j.ajhg.2008.09.005

19. Chung WC, Pak TR, Suzuki S, Pouliot WA, Andersen ME, Handa RJ. Detection and localization of an estrogen receptor beta splice variant protein (ERbeta2) in the adult female rat forebrain and midbrain regions. J Comp Neurol (2007) 505(3):249-67. doi:10.1002/cne.21490

20. Tsai PS, Moenter SM, Postigo HR, El Majdoubi M, Pak TR, Gill JC, et al. Targeted expression of a dominant-negative fibroblast growth factor (FGF) receptor in gonadotropin-releasing hormone $(\mathrm{GnRH})$ neurons reduces FGF responsiveness and the size of GnRH neuronal population. Mol Endocrinol (2005) 19(1):225-36. doi:10.1210/me.2004-0330

21. Sidhoum VF, Chan YM, Lippincott MF, Balasubramanian R, Quinton R, Plummer L, et al. Reversal and relapse of hypogonadotropic hypogonadism: resilience and fragility of the reproductive neuroendocrine system. JClin Endocrinol Metab (2014) 99(3):861-70. doi:10.1210/jc.2013-2809

22. Ornitz $\mathrm{DM}$, Itoh $\mathrm{N}$. The fibroblast growth factor signaling pathway. Wiley Interdiscip Rev Dev Biol (2015) 4(3):215-66. doi:10.1002/wdev.176

23. Schmahl J, Kim Y, Colvin JS, Ornitz DM, Capel B. Fgf9 induces proliferation and nuclear localization of FGFR2 in Sertoli precursors during male sex determination. Development (2004) 131(15):3627-36. doi:10.1242/dev.01239

24. Feng S, Xu J, Wang F, Kan M, McKeehan WL. Nuclear localization of a complex of fibroblast growth factor(FGF)-1 and an NH2-terminal fragment of FGF receptor isoforms R4 and R1alpha in human liver cells. Biochim Biophys Acta (1996) 1310(1):67-73. doi:10.1016/0167-4889(95)00146-8

25. Stachowiak EK, Fang X, Myers J, Dunham S, Stachowiak MK. cAMPinduced differentiation of human neuronal progenitor cells is mediated by nuclear fibroblast growth factor receptor-1 (FGFR1). J Neurochem (2003) 84(6):1296-312. doi:10.1046/j.1471-4159.2003.01624.x

26. Zammit C, Barnard R, Gomm J, Coope R, Shousha S, Coombes C, et al. Altered intracellular localization of fibroblast growth factor receptor 3 in human breast cancer. J Pathol (2001) 194(1):27-34. doi:10.1002/path.846

27. Bailey AP, Bhattacharyya S, Bronner-Fraser M, Streit A. Lens specification is the ground state of all sensory placodes, from which FGF promotes olfactory identity. Dev Cell (2006) 11(4):505-17. doi:10.1016/j.devcel.2006.08.009

28. Zhang X, Ibrahimi OA, Olsen SK, Umemori H, Mohammadi M, Ornitz DM. Receptor specificity of the fibroblast growth factor family. The complete mammalian FGF family. J Biol Chem (2006) 281(23):15694-700. doi:10.1074/ jbc.M601252200

29. Wray S, Grant P, Gainer H. Evidence that cells expressing luteinizing hormone-releasing hormone mRNA in the mouse are derived from progenitor cells in the olfactory placode. Proc Natl Acad Sci U S A (1989) 86(20):8132-6. doi:10.1073/pnas.86.20.8132

30. Schwanzel-Fukuda M, Pfaff DW. Origin of luteinizing hormone-releasing hormone neurons. Nature (1989) 338(6211):161-4. doi:10.1038/338161a0

31. Wray S, Nieburgs A, Elkabes S. Spatiotemporal cell expression of luteinizing hormone-releasing hormone in the prenatal mouse: evidence for an embryonic origin in the olfactory placode. Brain Res Dev Brain Res (1989) 46(2):309-18. doi:10.1016/0165-3806(89)90295-2

32. Forni PE, Bharti K, Flannery EM, Shimogori T, Wray S. The indirect role of fibroblast growth factor- 8 in defining neurogenic niches of the olfactory/GnRH systems. J Neurosci (2013) 33(50):19620-34. doi:10.1523/ JNEUROSCI.3238-13.2013
33. Kramer PR, Wray S. Nasal embryonic LHRH factor (NELF) expression within the CNS and PNS of the rodent. Brain Res Gene Expr Patterns (2001) 1(1):23-6. doi:10.1016/S1567-133X(01)00004-7

34. Kramer PR, Wray S. Midline nasal tissue influences nestin expression in nasal-placode-derived luteinizing hormone-releasing hormone neurons during development. Dev Biol (2000) 227(2):343-57. doi:10.1006/ dbio. 2000.9896

35. Halpern M. The organization and function of the vomeronasal system. Annu Rev Neurosci (1987) 10:325-62. doi:10.1146/annurev.ne.10.030187.001545

36. Farbman AI, Buchholz JA. Growth of olfactory epithelial tissue in vitro: lectin staining of axons. Microsc Res Tech (1992) 23(2):173-80. doi:10.1002/ jemt. 1070230207

37. Northcutt RG, Muske LE. Multiple embryonic origins of gonadotropinreleasing hormone $(\mathrm{GnRH})$ immunoreactive neurons. Brain Res Dev Brain Res (1994) 78(2):279-90. doi:10.1016/0165-3806(94)90037-X

38. Murakami S, Kikuyama S, Arai Y. The origin of the luteinizing hormonereleasing hormone (LHRH) neurons in newts (Cynops pyrrhogaster): the effect of olfactory placode ablation. Cell Tissue Res (1992) 269(1):21-7. doi:10.1007/BF00384722

39. el Amraoui A, Dubois PM. Experimental evidence for an early commitment of gonadotropin-releasing hormone neurons, with special regard to their origin from the ectoderm of nasal cavity presumptive territory. Neuroendocrinology (1993) 57(6):991-1002. doi:10.1159/000126490

40. Akutsu S, Takada M, Ohki-Hamazaki H, Murakami S, Arai Y. Origin of luteinizing hormone-releasing hormone (LHRH) neurons in the chick embryo: effect of the olfactory placode ablation. Neurosci Lett (1992) 142(2):241-4. doi:10.1016/0304-3940(92)90382-H

41. Arai Y, Murakami S, Seki T. Removal of olfactory placode prevents the development of LHRH neurons in the forebrain of the chick embryo: possible interaction between migrating LHRH neurons and highly polysialylated form of neural cell adhesion molecule (NCAM-H). Acta Biol Hung (1994) 45(2-4):155-68.

42. Whitlock KE, Westerfield $\mathrm{M}$. The olfactory placodes of the zebrafish form by convergence of cellular fields at the edge of the neural plate. Development (2000) 127(17):3645-53.

43. Forni PE, Taylor-Burds C, Melvin VS, Williams T, Wray S. Neural crest and ectodermal cells intermix in the nasal placode to give rise to GnRH-1 neurons, sensory neurons, and olfactory ensheathing cells. J Neurosci (2011) 31(18):6915-27. doi:10.1523/JNEUROSCI.6087-10.2011

44. Katoh H, Shibata S, Fukuda K, Sato M, Satoh E, Nagoshi N, et al. The dual origin of the peripheral olfactory system: placode and neural crest. Mol Brain (2011) 4:34. doi:10.1186/1756-6606-4-34

45. Schilling TF, Kimmel CB. Segment and cell type lineage restrictions during pharyngeal arch development in the zebrafish embryo. Development (1994) 120(3):483-94.

46. Raible DW, Eisen JS. Restriction of neural crest cell fate in the trunk of the embryonic zebrafish. Development (1994) 120(3):495-503.

47. Raible DW, Wood A, Hodsdon W, Henion PD, Weston JA, Eisen JS. Segregation and early dispersal of neural crest cells in the embryonic zebrafish. Dev Dyn (1992) 195(1):29-42. doi:10.1002/aja.1001950104

48. Whitlock KE, Wolf $\mathrm{CD}$, Boyce ML. Gonadotropin-releasing hormone $(\mathrm{GnRH})$ cells arise from cranial neural crest and adenohypophyseal regions of the neural plate in the zebrafish, Danio rerio. Dev Biol (2003) 257(1):140-52. doi:10.1016/S0012-1606(03)00039-3

49. Forni PE, Wray S. Neural crest and olfactory system: new prospective. Mol Neurobiol (2012) 46(2):349-60. doi:10.1007/s12035-012-8286-5

50. Ornitz DM. FGFs, heparan sulfate and FGFRs: complex interactions essential for development. Bioessays (2000) 22(2):108-12. doi:10.1002/ (SICI)1521-1878(200002)22:2<108::AID-BIES2>3.0.CO;2-M

51. Reuss B, von Bohlen und Halbach O. Fibroblast growth factors and their receptors in the central nervous system. Cell Tissue Res (2003) 313(2):139-57. doi:10.1007/s00441-003-0756-7

52. Boilly B, Vercoutter-Edouart AS, Hondermarck H, Nurcombe V, Le Bourhis X. FGF signals for cell proliferation and migration through different pathways. Cytokine Growth Factor Rev (2000) 11(4):295-302. doi:10.1016/S13596101(00)00014-9

53. Volosin M, Song W, Almeida RD, Kaplan DR, Hempstead BL, Friedman WJ. Interaction of survival and death signaling in basal forebrain 
neurons: roles of neurotrophins and proneurotrophins. J Neurosci (2006) 26(29):7756-66. doi:10.1523/JNEUROSCI.1560-06.2006

54. Olsen SK, Li JY, Bromleigh C, Eliseenkova AV, Ibrahimi OA, Lao Z, et al. Structural basis by which alternative splicing modulates the organizer activity of FGF8 in the brain. Genes Dev (2006) 20(2):185-98. doi:10.1101/ gad.1365406

55. Känsäkoski J, Fagerholm R, Laitinen EM, Vaaralahti K, Hackman P, Pitteloud N, et al. Mutation screening of SEMA3A and SEMA7A in patients with congenital hypogonadotropic hypogonadism. Pediatr Res (2014) 75(5): 641-4. doi:10.1038/pr.2014.23

56. Kawauchi S, Shou J, Santos R, Hébert JM, McConnell SK, Mason I, et al. Fgf8 expression defines a morphogenetic center required for olfactory neurogenesis and nasal cavity development in the mouse. Development (2005) 132(23):5211-23. doi:10.1242/dev.02143

57. Sabado V, Barraud P, Baker CV, Streit A. Specification of GnRH-1 neurons by antagonistic FGF and retinoic acid signaling. Dev Biol (2012) 362(2):254-62. doi:10.1016/j.ydbio.2011.12.016

58. Mott NN, Chung WC, Tsai PS, Pak TR. Differential fibroblast growth factor 8 (FGF8)-mediated autoregulation of its cognate receptors, Fgfr1 and Fgfr3, in neuronal cell lines. PLoS One (2010) 5(4):e10143. doi:10.1371/journal. pone. 0010143

59. Storm EE, Garel S, Borello U, Hebert JM, Martinez S, McConnell SK, et al. Dose-dependent functions of Fgf8 in regulating telencephalic patterning centers. Development (2006) 133(9):1831-44. doi:10.1242/dev.02324

60. Hoch RV, Clarke JA, Rubenstein JL. Fgf signaling controls the telencephalic distribution of Fgf-expressing progenitors generated in the rostral patterning center. Neural Dev (2015) 10(1):8. doi:10.1186/s13064-015-0037-7

61. Cholfin JA, Rubenstein JL. Frontal cortex subdivision patterning is coordinately regulated by Fgf8, Fgf17, and Emx2. J Comp Neurol (2008) 509(2):144-55. doi:10.1002/cne.21709

62. Fletcher RB, Baker JC, Harland RM. FGF8 spliceforms mediate early mesoderm and posterior neural tissue formation in Xenopus. Development (2006) 133(9):1703-14. doi:10.1242/dev.02342

63. Crossley PH, Minowada G, MacArthur CA, Martin GR. Roles for FGF8 in the induction, initiation, and maintenance of chick limb development. Cell (1996) 84(1):127-36. doi:10.1016/S0092-8674(00)80999-X

64. Bachler M, Neubuser A. Expression of members of the Fgf family and their receptors during midfacial development. Mech Dev (2001) 100(2):313-6. doi:10.1016/S0925-4773(00)00518-9

65. Crossley PH, Martin GR. The mouse Fgf8 gene encodes a family of polypeptides and is expressed in regions that direct outgrowth and patterning in the developing embryo. Development (1995) 121(2):439-51.

66. Moldrich RX, Gobius I, Pollak T, Zhang J, Ren T, Brown L, et al. Molecular regulation of the developing commissural plate. JComp Neurol (2010) 518(18):3645-61. doi:10.1002/cne.22455

67. Tanaka A, Miyamoto K, Minamino N, Takeda M, Sato B, Matsuo H, et al. Cloning and characterization of an androgen-induced growth factor essential for the androgen-dependent growth of mouse mammary carcinoma cells. Proc Natl Acad Sci U S A (1992) 89(19):8928-32. doi:10.1073/pnas.89. 19.8928

68. Yamanishi H, Tanaka A, Miyamoto K, Takeda M, Nishizawa Y, Koga M, et al. An essential role of androgen-induced growth factor in glucocorticoiddependent autocrine loop in Shionogi carcinoma 115 cells. J Steroid Biochem Mol Biol (1995) 52(1):49-53. doi:10.1016/0960-0760(94)00148-F
69. Gnanapragasam VJ, Robson CN, Neal DE, Leung HY. Regulation of FGF8 expression by the androgen receptor in human prostate cancer. Oncogene (2002) 21(33):5069-80. doi:10.1038/sj.onc.1205663

70. Linscott ML, Chung WC. Fibroblast growth factor 8 expression in GT1-7 GnRH-secreting neurons is androgen-independent, but can be upregulated by the inhibition of DNA methyltransferases. Front Cell Dev Biol (2016) 4:34. doi:10.3389/fcell.2016.00034

71. Denis H, Ndlovu MN, Fuks F. Regulation of mammalian DNA methyltransferases: a route to new mechanisms. EMBO Rep (2011) 12(7):647-56. doi:10.1038/embor.2011.110

72. Mic FA, Molotkov A, Benbrook DM, Duester G. Retinoid activation of retinoic acid receptor but not retinoid $\mathrm{X}$ receptor is sufficient to rescue lethal defect in retinoic acid synthesis. Proc Natl Acad Sci U S A (2003) 100(12):7135-40. doi:10.1073/pnas.1231422100

73. Minucci S, Leid M, Toyama R, Saint-Jeannet JP, Peterson VJ, Horn V, et al. Retinoid X receptor (RXR) within the RXR-retinoic acid receptor heterodimer binds its ligand and enhances retinoid-dependent gene expression. Mol Cell Biol (1997) 17(2):644-55. doi:10.1128/MCB.17.2.644

74. Mic FA, Molotkov A, Fan X, Cuenca AE, Duester G. RALDH3, a retinaldehyde dehydrogenase that generates retinoic acid, is expressed in the ventral retina, otic vesicle and olfactory pit during mouse development. Mech Dev (2000) 97(1-2):227-30. doi:10.1016/S0925-4773(00)00434-2

75. Layman LC. Clinical genetic testing for Kallmann syndrome. J Clin Endocrinol Metab (2013) 98(5):1860-2. doi:10.1210/jc.2013-1624

76. Kumar S, Duester G. Retinoic acid controls body axis extension by directly repressing Fgf8 transcription. Development (2014) 141(15):2972-7. doi:10.1242/dev.112367

77. MacDonald JL, Gin CS, Roskams AJ. Stage-specific induction of DNA methyltransferases in olfactory receptor neuron development. Dev Biol (2005) 288(2):461-73. doi:10.1016/j.ydbio.2005.09.048

78. Wu H, Zhang Y. Reversing DNA methylation: mechanisms, genomics, and biological functions. Cell (2014) 156(1-2):45-68. doi:10.1016/j.cell.2013. 12.019

79. Kagiwada S, Kurimoto K, Hirota T, Yamaji M, Saitou M. Replication-coupled passive DNA demethylation for the erasure of genome imprints in mice. EMBO J (2013) 32(3):340-53. doi:10.1038/emboj.2012.331

80. Schuermann D, Weber AR, Schar P. Active DNA demethylation by DNA repair: facts and uncertainties. DNA Repair (Amst) (2016) 44:92-102. doi:10.1016/j.dnarep.2016.05.013

81. Goldstein M, Meller I, Orr-Urtreger A. FGFR1 over-expression in primary rhabdomyosarcoma tumors is associated with hypomethylation of a 5' CpG island and abnormal expression of the AKT1, NOG, and BMP4 genes. Genes Chromosomes Cancer (2007) 46(11):1028-38. doi:10.1002/gcc.20489

Conflict of Interest Statement: The authors declare that the research was conducted in the absence of any commercial or financial relationships that could be construed as a potential conflict of interest.

Copyright $\odot 2016$ Chung, Linscott, Rodriguez and Stewart. This is an open-access article distributed under the terms of the Creative Commons Attribution License (CC $B Y)$. The use, distribution or reproduction in other forums is permitted, provided the original author(s) or licensor are credited and that the original publication in this journal is cited, in accordance with accepted academic practice. No use, distribution or reproduction is permitted which does not comply with these terms. 